\title{
VOZES DO NECROTÉRIO SOCIAL: O QUE PESSOAS EM SITUAÇÃO DE RUA TÊM A FALAR
}

\section{VOICES FROM THE SOCIAL MORGUE: WHAT HOMELESS PEOPLE HAVE TO SAY}

\author{
Caroline Francielle Alves ${ }^{1}$ \\ Viviane Pires Viana Silvestre ${ }^{2}$ \\ Sostenes Cezar de Lima³
}

\begin{abstract}
RESUMO: Este artigo tem como objetivo problematizar, sob uma ótica de(s)colonial, a lógica da colonialidade que impera sobre as pessoas em situaçăo de rua no Brasil. Para tanto, nos pautamos em Maldonado-Torres (2007, 2017, 2018), Quijano (2007), Spivak (2010), Mbembe (2016), entre outros/as. Trazemos um apanhado geral sobre as pessoas em situaçâo de rua no país, discutindo o processo de desumanizaçâo e morte desses sujeitos e problematizamos a condiçăo de fala da pessoa que se encontra socialmente morta. Apresentamos, entăo, duas narrativas de pessoas em situaçâo de rua, buscando compreender o que esses indivíduos têm a falar, pois é preciso combater o silenciamento que está intricado em grupos sociais minorizados. Essas narrativas foram construídas por meio de conversas realizadas em duas instituiçóes que atendem pessoas em situaçâo de rua em uma cidade de médio porte do Estado de Goiás. Ao trazer à tona essas vozes do necrotério social (REZENDE, 2017), empreendemos um esforço de(s)colonial, na expectativa de possibilitar que a sociedade que assiste, ou até mesmo pratica, violência e morte desses indivíduos consiga construir um atitude mínima de solidariedade emocional com essas vítimas (MAYA NETO, 2018).
\end{abstract}

PALAVRAS-CHAVE: Pessoas em situaçăo de rua. De(s)colonialidade. Silenciamento. Morte. Fala.

1 Mestranda no Programa de Pós-Graduaçăo Interdisciplinar em Educaçăo, Linguagem e Tecnologias da Universidade Estadual de Goiás, Anápolis-GO, Brasil.

2 Doutora em Letras e Linguística pela Universidade Federal de Goiás, com estágio de pós-doutoramento no mesmo Programa. Docente do curso de Letras: Português e Inglês e do Programa de Pós-Graduaçăo Interdisciplinar em Educaçăo, Linguagem e Tecnologias da Universidade Estadual de Goiás, AnápolisGO, Brasil.

3 Doutor em Linguística pela Universidade de Brasília. Docente do curso de Letras: Português e Inglês e do Programa de Pós-Graduaçâo Interdisciplinar em Educaçáo, Linguagem e Tecnologias da Universidade Estadual de Goiás, Anápolis-GO, Brasil. 
ABSTRACT: This article aims to problematize, from a decolonial perspective, the logic of coloniality that prevails over homeless people in Brazil. In order to do this, we have theoretically based the study in Maldonado-Torres (2007, 2017, 2018), Quijano (2007), Spivak (2010), Mbembe (2016), among others. We discuss the process of dehumanization and death of homeless people in the country and problematize the speech condition of the subject who is socially dead. We then present two homeless people's narratives, trying to understand what these individuals have to say, since it is necessary to combat silencing that is intricate in minority social groups. These narratives were constructed through conversations carried out in two institutions that serve homeless people in a medium-sized city in the state of Goiás. In bringing these voices of the social morgue (REZENDE, 2017) to the fore, we undertook a decolonial effort, in hopes of enabling the society that sees, or even practices, violence and death of these individuals to construct a minimum attitude of emotional solidarity with these victims (MAYA NETO, 2018).

KEYWORDS: Homeless people. Decoloniality. Silencing. Death. Speech.

\title{
CONSIDERAÇÕES INICIAIS
}

\begin{abstract}
Apenas em 2019 (e escrevo na primeira quinzena de abril), pelo menos oito - OITO moradores de rua foram queimados vivos no Brasil. Este é apenas um levantamento feito com base no noticiário, pode ser mais. Em 1 de janeiro, um morador de rua de 27 anos foi incendiado quando dormia em Ponta Grossa, no Paraná. Alguém passou, jogou álcool e colocou fogo no seu corpo. Teve mais de $40 \%$ do corpo queimado. Em 21 de janeiro, um morador de rua foi encontrado incendiado e morto numa praça de Curitiba, capital paranaense. Quatro dias depois, em 25 de janeiro, José Alves de Mello, 56 anos, também morador de rua, foi agredido e queimado num imóvel abandonado da Grande Curitiba. Em 27 de fevereiro, uma moradora de rua foi queimada quando dormia embaixo de um viaduto, no Recife, capital do estado de Pernambuco. Ela sobreviveu. Em 17 de março, José Augusto Cordeiro da Silva, 27 anos, acordou já em chamas embaixo de uma marquise na cidade de Arapiraca, no estado de Alagoas. Morreu no hospital. Em 1 de abril, um homem aparentando 30 e poucos anos morreu carbonizado próximo à escada rolante de uma estaçáo de trem em Santo André, no ABC Paulista. O caso foi registrado como "morte suspeita". Em 3 de abril, Roberto Pedro da Silva, 46 anos, foi incendiado quando dormia numa obra abandonada em Três Lagoas, em Mato Grosso do Sul. Um homem teria jogado combustível e ateado fogo em seu corpo. Em 7 de abril, um morador de rua aparentando 30 anos foi agredido a pedradas e incendiado no interior de um ginásio de esportes em Águas Lindas de Goiás, no entorno do Distrito Federal.
\end{abstract}

Se fôssemos gente decente de um país decente, pararíamos exigindo o fim da barbárie.

(BRUM, 2019)

O excerto que abre este texto explicita uma das facetas mais sangrentas e perversas da ferida colonial, definida por Walter Mignolo (2017) como a marca deixada nos damnés - condenados da terra (FANON, 1968). O racismo, que classifica e inferioriza 
determinados grupos como menos humanos, continua provocando feridas e morte. Instigadas/o pela provocaçáo de Eliane Brum, buscamos, neste texto, imprimir um pequeno esforço de(s)colonial (SILVESTRE, 2017) frente à atrocidade enfrentada pelas pessoas em situaçăo de rua em nosso país. Como afirma Mignolo (2018, p. 381 ${ }^{4}$, ênfase no original), "a de(s)colonialidade năo é nem um 'campo de estudo' nem uma 'disciplina', mas um modo de estar no mundo, interrogando as estruturas do conhecimento e do saber que nos foram lançadas".

À esteira de Tânia Rezende (2017, p. 281-282, ênfase no original), entendemos que as pessoas em situaçăo de rua fazem parte do que ela denomina como necrotério da sociedade, projeto "necessário para a manutençấo da colonialidade do saber e do poder", e, acrescentamos, do ser, para completar o tripé da estrutura opressora. No entendimento da autora, "corpos necrosados pela história, jogados na calçada do necrotério da sociedade nâo precisam de linguagem, nâo precisam nem de falar nem de ser escutados" (REZENDE, 2017, p. 281, ênfase no original). Contrariando essa lógica da colonialidade , este texto tem como objetivo trazer à tona vozes de pessoas em situaçáo de rua de uma cidade do Estado de Goiás, buscando compreender o que têm a falar e tendo como prisma de análise o campo que relaciona a Linguística Aplicada Crítica aos estudos de(s)coloniais. Isso porque "promover espaços de fala e garantir o merecimento da escuta é conferir poder, é decolonialidade do poder" (REZENDE, 2017, p. 287). Além disso, concordamos com a pesquisadora indiana Gayatri Spivak (2010) de que necessitamos combater o silenciamento que está intricado em grupos sociais minorizados, dentre os quais se encontra a populaçăo em situaçăo de rua.

As narrativas orais de duas pessoas em situaçăo de rua que discutiremos aqui fazem parte do material empírico de uma pesquisa de mestrado em andamento, realizada pela primeira autora deste texto. Essas narrativas ${ }^{6}$ foram construídas por meio de conversas, gravadas em áudio e posteriormente transcritas. Realizadas no primeiro semestre de 2017, as conversas aconteceram em uma casa de atendimento à populaçáo em situaçấo de rua, mantida pelo município, e em uma casa de reabilitaçấo para pessoas em estado de mendicâncias, custeada por uma instituiçấo religiosa. Ambas as instituiçōes estâo localizadas em uma cidade de médio porte do Estado de Goiás. Nessas instituiçóes, săo distribuídos alimentos, roupas e cobertores para pessoas que estâo em situaçăo de rua. No horário de distribuiçăo de alimentos, Oswaldo Silva e Joăo José nos narraram suas histórias de vida. As transcriçōes dessas narrativas, juntamente com o diário de campo da pesquisadora, compóem o material empírico deste trabalho, que se insere no escopo da Pesquisa Qualitativa (DENZIN; LINCOLN, 2013).

Além desta seçâo introdutória e das consideraçōes finais, este artigo está

4 Todas as traduçóes de trechos originalmente em inglês ou espanhol foram feitas por nós.

5 Como afirma Nelson Maldonado-Torres (2017, p. 117), "é amplamente reconhecido hoje que a colonialidade nâo é apenas colonialismo. Enquanto o colonialismo é tipicamente considerado um arranjo político que existiu desde tempos imemoriais, colonialidade refere-se à lógica, cultura e estrutura do sistema mundial moderno". É o lado obscuro da modernidade, como defende Walter Mignolo (2012).

6 As narrativas apresentadas neste artigo resultam da transcriçăo das conversas realizadas entre a primeira autora e duas pessoas em situaçấo de rua. A primeira narrativa, de Joâo José, deriva de uma entrevista que durou 5min4s. A segunda narrativa, de Oswaldo Silva, foi construída a partir de uma entrevista que durou $5 \mathrm{~min} 18 \mathrm{~s}$. A gravaçáo das entrevistas foi autorizada pelos participantes, e o material em áudio está sob a guarda das autoras e do autor deste artigo. 
organizado em três seçôes: na primeira, apresentamos um apanhado geral sobre as pessoas em situaçăo de rua no Brasil, discutindo o processo de desumanizaçăo e morte desses sujeitos; na sequência, problematizamos a condiçăo de fala da pessoa que se encontra socialmente morta; e, por último, analisamos o que duas pessoas em situaçáo de rua têm para falar a partir de suas histórias de vida que nos foram narradas.

\section{PESSOAS EM SITUAÇÃO DE RUA NO BRASIL}

O decreto n. 7.053, de 23 de dezembro de 20097' que institui a política nacional para a populaçăo em situaçăo de rua, define esse grupo social da seguinte maneira:

[...] grupo populacional heterogêneo que possui em comum a pobreza extrema, os vínculos familiares interrompidos ou fragilizados e a inexistência de moradia regular, que utiliza os logradouros públicos e as áreas degradadas como espaço de moradia e de sustento, de forma temporária ou permanente, bem como as unidades de acolhimento para pernoite temporário ou como moradia provisória. (BRASIL, 2009a, Art. 1 , Parágrafo Único).

A Pesquisa Nacional Censitária e Por Amostragem realizada sob a coordenaçáo do Ministério do Desenvolvimento Social e Combate à Fome tentou traçar um perfil para esse grupo de pessoas. No relatório da pesquisa, publicado no ano de 2009, o Ministério do Desenvolvimento Social e Combate à Fome indicou haver um total de 31.922 pessoas adultas em situaçăo de rua no Brasil. A pesquisa ocorreu entre os anos de 2007 e 2008; foram pesquisadas apenas 71 cidades, incluindo as capitais e grandes centros urbanos brasileiros. Porém, se as demais cidades do país fossem incluídas, a estimativa de 2009 é que existiam 50.000 pessoas em situaçăo de rua (BRASIL, 2009b). Em 2015, os números dobraram. Segundo o Instituto de Pesquisa Econômica Aplicada (IPEA, 2015), acredita-se que havia, naquele ano, 101.854 pessoas em situaçâo de rua no Brasil, sobrevivendo em condiçōes de extrema instabilidade.

Para compreendermos esse fenômeno no Brasil, recorremos às discussóes teórico-políticas desenvolvidas pelo Grupo Modernidade/Colonialidade, que tem o teórico social Aníbal Quijano como um dos fundadores. De acordo com Luciana Balestrin (2013, p. 110),

Dentre as contribuiçóes consistentes do grupo, estăo as tentativas de marcar: (a) a narrativa original que resgata e insere a América Latina como o continente fundacional do colonialismo, e, portanto, da modernidade; (b) a importância da América Latina como primeiro laboratório de teste para o racismo a serviço do colonialismo; (c) o reconhecimento da diferença colonial, uma diferença mais difícil de identificaçăo empírica na atualidade, mas que fundamenta algumas origens de outras diferenças; (d) a verificaçăo da estrutura opressora do tripé colonialidade do

$7 \quad$ Os art. $9^{\circ}$ ao art. 14 foram revogados pelo decreto n. 9.894, de 27 de junho de 2019, que dispóe sobre o Comitê Intersetorial de Acompanhamento e Monitoramento d política Nacional para a Populaçáo em Situaçấo de Rua. Disponível em: http://www.planalto.gov.br/ccivil_03/_Ato2019-2022/2019/Decreto/ D9894.htm\#art9. Acesso em: 08 jul. 2019. 
poder, saber e ser como forma de denunciar e atualizar a continuidade da colonizaçăo e do imperialismo, mesmo findados os marcos históricos de ambos os processos; (e) a perspectiva decolonial, que fornece novos horizontes utópicos e radicais para o pensamento da libertaçăo humana, em diálogo com a produçăo de conhecimento.

Quijano (2007) explica que, com o processo de colonizaçâo da denominada América Latina pelos Europeus, os sujeitos passam a ser identificados de acordo com sua raça (índios, negros e mestiços). Portanto, "raça e identidade racial foram estabelecidas como instrumentos de classificaçâo social básica da populaçăo" (QUIJANO, 2007, p. 117). Anteriormente, as identidades eram marcadas por procedência geográfica de origem. Com a colonizaçăo, essas identidades passaram a marcar hierarquias, lugares e papéis sociais que o sujeito, cujo corpo se tornou racializado, poderia desempenhar na sociedade. Assim, no cenário da colonizaçăo, os negros foram subalternizados, tornando-se uma força de trabalho, um corpo a ser explorado (QUIJANO, 2007).

No Brasil, após a promulgaçăo da lei de aboliçâo da escravatura em 1888 (Lei imperial n. 3.353, de 13 de maio 1888), as pessoas negras continuaram em situaçấo de subalternidade. 0 preconceito racial instaurado no período da escravidấo continuou limitando o acesso dessas pessoas a condiçóes de vida dignas. Assim, uma grande parcela da populaçăo foi, sob o signo da lei, simplesmente abandonada e, até mesmo, criminalizada. Essa criminalizaçấo e o abandono da populaçăo negra no Brasil se tornaram legalizadas, conforme se vê no Código Penal de 1890 (Decreto n. 847, de 11 de outubro de 1890). O referido documento, no Livro III, acerca das contravençóes penais, estabelecia que a mendicância e práticas como a capoeira eram passíveis de puniçâo. Essas práticas fazem uma referência direta à parcela da populaçăo que estava, após a aboliçăo da escravidâo, desempregada e vivendo nas ruas.

Essas marcas de colonialidade - resquícios que sobrevivem ao colonialismo que a antecedeu - trazem consequências no entendimento da constituiçăo da populaçăo em situaçăo de rua no Brasil atual. Uma pesquisa realizada pelo IBGE em $2017^{8}$ apontou que a maioria das pessoas que estâo fora do mercado de trabalho formal é constituída por pessoas negras. Isso está diretamente ligado ao contingente de pessoas em situaçăo de rua. Assim, a vida e a morte nas ruas têm cor, têm corpo marcado.

Segundo o Ministério de Desenvolvimento Social e Combate à Fome,

$39,1 \%$ das pessoas em situaçăo de rua se declararam pardas. Essa proporçăo é semelhante à observada no conjunto da populaçăo brasileira (38,4\%). Declararamse brancos 29,5\% (53,7\% na populaçăo em geral) e pretos 27,9\%, (apenas 6,2\% na populaçăo em geral). Assim, a proporçăo de negros (pardos somados a pretos) é substancialmente maior na populaçăo em situaçăo de rua. (BRASIL, 2008, p. 6-7).

O grupo de pessoas em situaçáo de rua constitui "uma parcela da populaçăo brasileira [que sobrevive] nos limites inferiores da pobreza e de vulnerabilidade" (BRASIL, 2009b, p. 101). O grupo é constituído de sujeitos que, "além de extremamente pobres, săo escassamente escolarizados e se compóe predominantemente de negros, que,

8 Dado disponível em: https://g1.globo.com/economia/noticia/637-dos-desempregados-no-brasil-saopretos-ou-pardos-aponta-ibge.ghtml. Acesso em: 05 abr. 2019. 
embora estando predominantemente em idade economicamente ativa, năo conseguem inserçâo no mercado formal de trabalho" (BRASIL, 2009b, p. 101). Além disso, o Boletim Epidemiológico 14, publicado pelo Ministério da Saúde em junho de 2019 e que apresenta uma análise das notificaçóes de violência contra a populaçăo em situaçăo de rua no Brasil de 2015 a 2017, apontou que, nesse período,

[...] foram notificados 777.904 casos de violência; destes, em 17.386 (2,2\%), a motivaçăo principal foi a condiçăo de situaçăo de rua da vítima. [...] As notificaçóes de violência motivada por situaçăo de rua foram mais frequentes em indivíduos do sexo feminino (50,8\%), e entre as pessoas da raça/cor da pele negra (pretos e pardos), com 9.522 (54,8\%). (BRASIL, 2019, p. 3).

Compreendemos, assim, que a populaçăo em situaçâo de rua herdou o abandono social do período escravocrata e pós-aboliçâo, por isso seus corpos-políticos sáo marcados como inferiores, como figuras da desumanidade, uma vez que raça - e gênero também, como aponta o boletim - será determinante para autorizar que corpos devem ser violentados. Desse modo, essas pessoas continuam vivas, mas sobrevivendo em um "mundo de horrores, crueldade e profanidade intensos" (MBEMBE, 2016, p. 31). O teórico político e historiador camaronês Achille Mbembe (2016) alerta que essa vida de horrores produz a desumanizaçáo desses sujeitos e, consequentemente, sua morte social:

[...] a condiçáo de escravo resulta de uma tripla perda: perda de um 'lar', perda de direitos sobre seu corpo e perda de status político. Essa perda tripla equivale a dominaçâo absoluta, alienaçăo ao nascer e morte social (expulsâo da humanidade de modo geral). (MBEMBE, 2016, p. 131, ênfase no original).

É importante salientar que o sistema capitalista, em sociedades remanescentes do colonialismo escravagista, ainda mantém em sua estrutura os valores e padróes coloniais escravocratas, que buscam eliminar determinados grupos sociais. Para isso, o terror colonial se entrelaçou com "fantasias geradas colonialmente, caracterizadas por terras selvagens, morte e ficçóes para criar um efeito real" (MBEMBE, 2016, p. 134), produzindo na sociedade "o desejo pela eliminaçâo sistemática daqueles corpos que poluem a pureza de uma naçăo imaginada, um tipo de 'correia de transmissăo' de uma Europa também imaginada: branca, racional, cristă, heterossexual" (BENTO, 2018, p. 4, ênfase no original). Como denuncia Maya Neto (2018, p. 164), "os massacres têm sido parte integral da colonialidade". Assim, as calçadas, as ruas e os viadutos das cidades se configuram como o necrotério da sociedade, um lugar de eliminaçáo dos corpos racializados que náo conseguiram ser integrados à sociedade, como apontado por Rezende (2017). Nesse sentido, a fantasia criada pelo colonialismo continua construindo um desfecho real e cruel para os sujeitos que foram marcados e hierarquizados (MBEMBE, 2016).

\section{QUEM ESTÁ MORTO/A SOCIALMENTE PODE FALAR?}

A língua está constitutivamente imbricada em relaçōes de poder que săo estabelecidas cultural e socialmente, determinando lugares sociais a partir do qual o sujeito 
pode ou năo falar, quando fala e se tem ou năo merecimento de escuta. Gayatri Spivak (2010), em seu livro Pode o subalterno falar?, usa o termo "subalterno" para se referir aos sujeitos que "estăo situados nas camadas mais baixas da sociedade constituídas pelos modos específicos de exclusăo dos mercados, da representaçăo política e legal, e da possibilidade de se tornarem membros plenos no estrato social dominante" (SPIVAK, 2010, p. 8). Nesse sentido, os sujeitos subalternizados săo "pessoas de regiōes e grupos que estăo fora do poder da estrutura hegemônica" e, consequentemente, "do pensamento hegemônico" (SPIVAK, 2010, p. 84).

A indagaçâo sociopolítica proposta por Spivak (2010), “Pode o subalterno falar?", problematiza o quadro de monopólio discursivo exercido por certos grupos sociais. Chamamos aqui de monopólio discursivo o controle que os grupos sociais hegemônicos detêm sobre as agendas discursivas. Uma agenda discursiva é construída a partir de, pelo menos, quadro elementos: a) objetos discursivos - itens que podem e devem ser narrativizados/discursivizados; b) modos de representaçăo discursiva - maneira como os objetos de discurso săo narrativizados/discursivizados; c) sujeitos sociais de fala - sujeitos/posiçôes sociais que podem exercer de forma privilegiada (e, em alguns casos, de forma exclusiva) o direito de fala; d) meios de produçăo e mediaçăo discursiva - conjunto de tecnologias simbólicas que permitem a produçăo, registro e difusâo dos discursos. É importante salientar que as agendas discursivas estăo sempre carregadas de permissóes e interdiçôes. O monopólio das agendas se dá quando determinados grupos sociais detêm as permissōes discursivas e podem impor a outros grupos sociais uma série de interdiçôes e constriçōes discursivas.

A situaçăo de rua ilustra bem a questăo do "poder de fala". As pessoas em situaçăo de rua, por estarem fora das estruturas hegemônicas de poder, têm o seu direito de fala restringido, interditado. Na condiçáo de subalternizado, a pessoa em situaçâo de rua é impedida de construir uma agenda discursiva sobre o mundo e a condiçâo social em que vive. Náo pode narrar/representar sua experiência identitária e sua trajetória social. Năo pode falar sobre a supressăo de seus direitos sociais e políticos. Năo detém poder sobre os meios de produçâo e mediaçăo simbólica. Em um quadro de controle de agenda discursiva exercido pelos grupos hegemônicos, resta à pessoa em situaçấo de rua apenas lugar de subalternizado, o lugar de quem só pode ser representado e identificado pelo discurso do outro, o lugar de quem năo pode e nem deve falar.

Maldonado-Torres (2018, p. 111) afirma que "um dos aspectos mais letais da colonialidade é a sensaçâo de que certos sujeitos e povos, assim como a maioria dos aspectos associados a eles, sâo ambos inferiores, em comparaçăo ao que é considerado normal [...]". Nesse sentido, "seus desejos, aspiraçôes e concepçóes do que é ser humano sâo definidos de antemâo por estruturas, culturas, símbolos que consideram aspectos como a indigeneidade e a negritude, além de outros marcadores da condenaçăo, como sinais de miséria e animalidade" (MALDONADO-TORRES, 2018, p. 111). Diante disso, a parcela da populaçăo abandonada e exposta à violência e morte no país continua sendo, como no período escravocrata, majoritariamente, o corpo-político negro e extremamente pobre. Como defende Mbembe (2016), a morte social desses sujeitos é causada pela perda do lar, da vida política e dos direitos sobre si.

$\mathrm{O}$ acesso aos espaços e instituiçōes sociais hegemônicos garante a certos grupos sociais o direito de participar dos discursos e saberes hegemônicos. Isso significa dizer 
que os grupos sociais que gozam do privilégio da nâo marcaçăo racial, gozam também do privilégio de participar livremente da vida social em suas diversas dimensôes. Em contrapartida, o bloqueio no acesso aos espaços e instituiçôes de poder restringe (para nâo dizer elimina) as oportunidades de participaçăo nos discursos e práticas hegemônicas. Assim, os grupos sociais impedidos de participar da vida social năo săo apenas impedidos de participar dos discursos e saberes hegemônicos, săo também impedidos de fazer valer seus próprios discursos e saberes. Há, assim, dois movimentos de morte social: um que impede a dignidade social e outro que condena à inexistência social.

Djamila Ribeiro (2017, p. 36-37) argumenta que

[...] năo poder acessar certos espaços, acarreta em năo se ter produçōes e epistemologias desses grupos nesses espaços; năo poder estar de forma justa nas universidades, meios de comunicaçăo, política institucional, por exemplo, impossibilita que as vozes dos indivíduos desses grupos sejam catalogadas, ouvidas, inclusive, até de quem tem mais acesso à internet. $O$ falar năo se restringe ao ato de emitir palavras, mas de poder existir. Pensamos lugar de fala como refutar a historiografia tradicional e a hierarquizaçấo de saberes consequente da hierarquia social.

Desse modo, o lugar silenciado (SPIVAK, 2010), constituído para esses sujeitos, atrelado à legitimaçáo de sua náo existência, abre espaço para o campo de morte. A situaçăo é tăo grave e violenta que a morte dos subalternizados rompe, em muitos casos, a barreira do social para atacar diretamente o corpo, conforme vimos no texto de Eliane Brum. Ribeiro (2017) aponta ainda que o náo direito de fala dos grupos subalternizados é justificado pelo nâo reconhecimento de sua humanidade: "As experiências desses grupos localizados socialmente de forma hierarquizada e năo humanizada fazem com que as produçóes intelectuais, saberes e vozes sejam tratadas de modo igualmente subalternizado, além das condiçôes sociais os manterem num lugar silenciado estruturalmente" (RIBEIRO, 2017, p. 36).

Notamos, nas conversas com os sujeitos que participaram da pesquisa, uma conformaçăo com o lugar e condiçăo de silêncio. Em uma anotaçăo do diário de campo, a primeira autora registrou essa impressăo:

Oindivíduo pesquisado se propóe a realizar a entrevista e logo no início me questiona: "Você năo tem vergonha de estar falando comigo?" Respondi que năo. E logo depois, chorando, ele se levanta e diz: "Eu tenho vergonha de falar com você!". Ele sai por năo se sentir digno de manter o diálogo. (Diário de campo, 10 de maio de 2017).

O conceito de damné, cunhado por Fanon (1968) e explicado por Maldonado-Torres (2007), pode nos ajudar a entender a atitude do homem em situaçăo de rua que se nega a conversar com a mulher branca que queria entrevistá-lo. De acordo com MaldonadoTorres (2007, p. 151, ênfase adicionada), damné, ou condenado da terra, "é, literalmente, o sujeito que náo pode dar porque o que ele ou ela é foi tirado dele ou dela". Ainda que a interlocutora demonstre uma escuta empática (REZENDE, 2017), ele náo se sente capaz/digno de falar a ela. A sensaçăo de inferioridade falou mais alto.

Nesse contexto, o discurso que hierarquiza e racializa o outro é assimilado, fazendo 
com que as pessoas subalternizadas se sintam indignas de falar. Carlos Figueiredo (2010) chama a atençâo para os perigos da apropriaçăo do outro. O autor enfatiza a necessidade de uma utopia que reescreva das estruturas da hierarquizaçăo social; uma utopia que fortaleça a coexistência, em lugar da assimilaçăo do outro. Desse modo, dialogando com a teoria de Spivak (2010), o pesquisador demonstra que o discurso do sujeito nâo marcado, que ocupa uma posiçăo de poder nas estruturas e relaçóes sociais fica "enraizado na consciência do mais fraco; sinteticamente, trata-se de ouvir a voz do outro em nós" (FIGUEIREDO, 2010, p. 86).

Outro fato relacionado à ida da primeira autora ao campo de pesquisa nos chama atençăo para esse silenciamento estrutural. Das dez pessoas em situaçăo de rua convidadas para colaborar com o estudo, somente quatro se propuseram a participar. Dos seis participantes que se negaram a participar, quatro eram mulheres. Năo descartando a possibilidade dessa recusa/silêncio ter sido "uma estratégia de defesa, ou [...] desconfiança d[a] pesquisador[a]" (JOVCHELOVITCH; BAUER, 2002, p. 105), o que mais nos intriga é que uma dessas mulheres havia consentido participar da pesquisa. Contudo, logo depois do consentimento, seu companheiro a chama dizendo que estavam atrasados. Ela responde que seria rápido, porém ele reafirma que precisavam ir embora. A situaçâo foi registrada da seguinte maneira no diário de campo:

O que nos chamou atençăo em um dos convites para a entrevista foi que o marido de uma das mulheres em situaçăo de rua năo a deixou participar da entrevista (Diário de campo, 22 de junho de 2017).

Percebemos, assim, que as mulheres em situaçăo de rua săo silenciadas em múltiplas dimensóes. Elas săo silenciadas pelos discursos e grupos sociais hegemônicos, em razâo da condiçăo social e racial, e pela dominaçăo masculina dentro do grupo subalternizado. Nesse sentido, concordamos com Spivak (2010, p. 14-15): "a mulher subalterna se encontra em uma posiçấo ainda mais periférica pelos problemas subjacentes à questâo de gênero". O marido, quando nâo permite que a mulher em situaçăo de rua possa falar, silencia sua história, já que "se o sujeito subalterno năo tem história e náo pode falar, o sujeito subalterno feminino está ainda mais na profundidade, na obscuridade" (p. 14-15). Ressaltamos aqui a necessidade de realizar novas pesquisas, com metodologias que sejam capazes de fazer emergir as narrativas de mulheres em situaçăo de rua, com vistas a demonstrar esse cenário de múltiplos silenciamentos no qual estăo imersas.

É importante ressaltar que a consciência subalterna resulta de processo sóciohistórico consistente de construçâo da universalizaçâo de identidade - vista como neutra, năo marcada - e da racializaçáo e subalternizaçăo de outras. Tayane Lino (2015, p. 71), dialogando com a teoria de Spivak (2010), entende que a "consciência subalterna" năo é natural, nem parte da essência dos integrantes desse grupo; ao contrário, "é uma construçấo coletiva do seu lugar como subalterno, das relaçôes de poder que produzem e reiteram o lugar desses como subalternos". Por outro lado, ao argumentar que o sujeito subalternizado năo pode falar, a pesquisadora năo nega que haja clamor, desejo ou protesto desse grupo/sujeito em falar (LINO, 2015). Assim, contrariando a lógica de colonialidade, temos o registro de narrativas de pessoas em situaçáo de rua em que há clamor pela fala, como veremos a seguir. 


\section{O QUE PESSOAS EM SITUAÇÃO DE RUA TÊM A FALAR}

Spivak (2010, p. 13) alerta "para o perigo de construir o subalterno apenas como objeto de conhecimento por parte de intelectuais que almejam falar pelo outro". Portanto, pesquisas com grupos/indivíduos marginalizados devem atentar para năo entender esse grupo/indivíduo como uma espécie de objeto a ser conhecido pelo estudioso que deseja falar pelo "outro". A educadora indígena Linda Smith (2012), ao discutir metodologias decoloniais de pesquisa, diz que, por vezes, a pesquisa científica é construída tomando o objeto investigado como năo tendo "força de vida, humanidade, ou espírito próprio, e assim, năo pode dar uma contribuiçăo ativa" (SMITH, 2012, p. 64). Cientes desse risco, náo almejamos neste estudo simplesmente falar pelas pessoas em situaçâo de rua, mas, na medida do possível, falar com elas. Ao apresentarmos, nesta seçâo, as narrativas de Joâo José e Oswaldo Silva, esperamos que este texto se constitua como um espaço de fala para pessoas em situaçâo de rua. Assim, convidamos o leitor ou a leitora para uma escuta atenta e empática para com suas vozes, buscando possibilidades de narrativas e histórias outras que podemos construir a respeito dessas pessoas. Buscamos pensar de outro modo (PENNYCOOK, 2012) a respeito desses indivíduos, diferentemente do modo como as narrativas modernas/coloniais nos fizeram/fazem acreditar. Assim, chegamos ao cerne deste estudo: o que as vozes do necrotério social têm a falar? Segue a narrativa de Joăo José:

[Pode nos contar um pouco da sua história de vida??]

Eu tenho 25 anos e moro em situaçáo de rua. Eu conheci as ruas aos doze anos de idade, fugindo de casa devido ao meu relacionamento familiar. Aos quatorze anos conheci as substâncias químicas, as drogas e o crime; de lá para cá eu me aprofundei nesse mundo. Aos dezenove anos eu consegui parar, me casei e tive um filho. Hoje meu filho tem dez anos de idade. Quando me casei, fiquei três anos de casado. Entăo posteriormente me separei. Ao me separar, comecei a fazer o uso absurdo de substâncias químicas. Foi uma coisa bem mais obsessiva e compulsiva, ou seja, eu me aprofundei realmente. Hoje eu consigo passar dias abstinente, mas eu ainda tenho dias de recaídas. Atualmente me encontro bem. Consegui terminar meus estudos, tenho um bom currículo. Porém, a rua năo é bom! Se eu falar que a rua é bom! Năo é bom! É cansativo, é estressante, é perigoso. Porém, querendo ou năo a gente aprende a gostar. Mesmo você morando na rua, dormindo no papelăo, tendo que pedir um prato de comida, mesmo precisando disso, a gente acaba gostando e isso se torna um vício. A rua vicia! A verdade é que a rua vicia; năo a droga, mas a rua em si. 0 companheirismo e até mesmo os inimigos faz a gente gostar das ruas. Hoje graças a Deus eu me encontro bem; voltei a ter um relacionamento com minha família. Estou em situaçăo de rua ainda, mas tenho um apoio, eles ainda me ajudam. E um dia de cada vez, eu vou levando a vida.

[Como é estar em situaçăo de rua?]

Vejo todos os dias violências nas ruas.

9 As interferências entre colchetes dizem respeito às intervençóes ou comentários da pesquisadora. 
[Você já vivenciou alguma violência nas ruas?]

Eu vi uma grande amiga minha morrer. Foi o que mais me assustou. Ela era casada há quatro anos. Ela tinha uma dívida e alguns indivíduos chegaram para sequestrar e năo conseguiram. E ali mesmo acabaram alvejando ela com dois disparos de arma de fogo. O que mais me deixou encabulado, nessa situaçăo, inclusive passei alguns dias traumatizado, meio ruim, foi que o marido que era casado com ela há quatro anos... Assim que ela morreu, a primeira coisa que ele fez foi enfiar a máo no bolso dela e pegar a droga. Entăo, ou seja, ... né? Hoje em dia, no mundo, năo se tem mais amor. Eu, por exemplo, sofri inúmeras violências policiais; apanhei da polícia sem motivos. Hoje em dia eu me encontro bem, mas já pratiquei muitos furtos e muitos assaltos. Eu quero deixar um recado, já que estou falando. Eu quero deixar um recado, assim, para que possa mudar e ajudar as pessoas em situaçáo de rua. Sobre o morador de rua, o vigia de carro, o vendedor de balinha, o cara que pede no sinal, muitas vezes ele chega com boa intençâo, sem maldade nenhuma; ele vem para conseguir seu sustento. Às vezes as pessoas falam: "está pedindo". Porém, ninguém dá um emprego. Muitas pessoas param no sinal... é empresário, fazendeiro, mas năo arruma emprego. Quando a pessoa chega, fecha o vidro. Quando ele está vigiando um carro e vai receber, a pessoa sai sem pagar. Isso aí, você está formando um ladrâo, né? Você tá gerando uma revolta. Você está gerando um ladrâo. E aí é simples. Ele chega para te pedir, para receber de um carro e você vai embora. E quando chega e bota um revólver dentro da sua boca, o que você faria? Entăo, năo faz isso năo. Se você năo tem condiçôes de ajudar, também năo maltrata! Quem faz o ladrăo é você! É a própria sociedade. É essa política falha e corrupta que faz o ladrăo. Eu estou deixando esse recado para ver se muda essa situaçăo. Isso gera uma revolta grande no meu coraçăo. Eu vi muitos amigos meus deixar de pedir, de vender balinha, de vigiar carros para virar ladrăo devido a essa situaçáo, na qual a própria sociedade cria. Era isso que eu tinha para dizer!

Os abusos familiares levaram Joăo José a ir para as ruas aos 12 anos de idade. Ainda criança lhe foi negado todos os seus diretos básicos de vida. O rompimento do laço afetivo familiar, na infância e posteriormente na vida adulta, o leva a viver nas ruas e a usar substâncias químicas. É assim que Joâo José vai se enraizando nas ruas, passando a vivenciar um processo lento e gradativo de desumanizaçăo, ou seja, passando a ser entendido como menos humano. Por outro lado, em sua narrativa, Joăo José mostra seu lado mais humano, ao sentir compaixăo pela morte da amiga, friamente assistida por seu companheiro. Joâo José relata como ficou impactado e comovido com aquela cena.

A despeito da situaçăo em que se encontra, Joâo José considera que está bem e aprendeu a gostar das ruas, como que um vício. Sua narrativa sugere que, apesar de a sociedade lhe negar humanidade, ele năo se considera como alguém desumanizado. Tomando como base a análise proposta por Mbembe (2016), notamos que nega ter perdido os elementos sociais usados para autenticar a condiçăo humana: ele tem a possibilidade de um lar, visto que mantem contato com a família; ele tem possibilidade de usufruir dos outros dois direitos (sobre o próprio corpo e político), já que "conseguiu terminar os estudos e tem um bom currículo" (padrăo hegemônico de bom cidadăo). A questăo que fica é: O que, de fato, mantem Joăo José nas ruas?

Joâo José mostra, em sua fala, uma indignaçăo com o modo como é representado pelo discurso do outro, como um pedinte que nâo trabalha. Para Joâo José, a representaçâo 
identitária construída pelo outro năo leva em conta o quadro social de profunda negaçâo em que vive a pessoa em situaçâo de rua: Às vezes as pessoas falam: "está pedindo". Porém, ninguém dá um emprego. Muitas pessoas param no sinal... é empresário, fazendeiro, mas nâo arruma emprego. Joâo José reivindica que o seu (nâo)lugar social seja reconhecido como um fator desencadeador de sua condiçâo. A identificaçăo que o outro constrói para ele é unilateral, baseada apenas no lugar social ocupado pelos sujeitos que podem contar com a proteçâo do Estado e da sociedade em geral.

Maldonado-Torres (2017) alerta que a virada de(s)colonial de Fanon é baseada na súplica ao corpo de sempre ser questionador. O filósofo porto-riquenho defende que “o sujeito/corpo vulnerável que procura estar aberto e fazer perguntas torna-se um indicador de um senso de humanidade que os damnés e outros que se juntam a eles/as podem reivindicar em comum na luta pela de(s)colonizaçăo" (MALDONADO-TORRES, 2017, p. 131). Joâo José faz esse movimento de reinvindicaçấo em sua narrativa: Eu quero deixar um recado, já que estou falando. Eu quero deixar um recado, assim, para que possa mudar e ajudar as pessoas em situaçâo de rua.

A conversa com a pesquisadora é vista como um espaço de fala: Eu quero deixar um recado, já que estou falando. Joăo José nota haver ali uma situaçăo de escuta atenta e engajada, um espaço no qual pode valer seu direito de falar sobre a vida, sobre sua condiçáo. Sente que sua fala pode ser um instrumento político que pode mudar e ajudar as pessoas em situaçâo de rua.

A pergunta E quando chega e bota um revólver dentro da sua boca, o que você faria? expressa, ainda, a indignaçáo de Joâo José em relaçâo ao outro que o despreza e o vê como inferior/indigno de ser visto ou escutado. Cansando de gritar alto e nunca ser atendido, ele passa a entender que só há uma forma de ser visto ou escutado, ou seja, quando é violento. Por isso, Joăo José faz uma reflexăo sociológica, demonstrando que a violência é gerada pelo descaso da sociedade em relaçấo à pobreza extrema, sendo perceptível em sua narrativa o desejo de que essa situaçăo mude. Joăo José narra o quanto foi desprezado pela sociedade em toda sua trajetória de vida, e expressa o desejo de que outras pessoas năo passem por isso. Em sua súplica, Joăo José afirma que a violência exercida - năo a sofrida - nada mais é, nesse contexto, do que uma forma de resistir ou existir em uma sociedade que o violentou durante toda sua vida: Se você nâo tem condiçōes de ajudar, também, nâo maltrata! Quem faz o ladrāo é você!

Resende (2016) constata que as pessoas em situaçâo de rua aparecem associadas em textos jornalísticos à violência. Como consequência, surge na sociedade o desejo do expurgo desses sujeitos, o que acarreta a estagnaçâo/aumento da situaçấo de violência sofrida contra esse grupo de pessoas. Assim, as ruas vâo se tornando espaços de morte e seres humanos vấo sendo eliminados pelo simples fato de existirem. Em outras palavras, essas pessoas vấo sendo mortas por expor seus corpos de miséria em espaços públicos. Assim, verdadeiros necrotérios sociais văo sendo criados, com o objetivo de isolar e eliminar esses indivíduos.

Na sequência, passamos para a segunda narrativa: 
Eu nasci no Rio de Janeiro. Sai do Rio de Janeiro por causa de divergência familiar. Familiar... eu quero dizer é entre a minha pessoa e a mulher que morava comigo na época [silêncio]. Um caso de aborto. Ela queria fazer um aborto e eu era contra. Entăo, ela fez contra minha vontade. Por isso tive que sumir do Rio. Porque a família dela era de sete irmáos e a minha família treze homens e uma mulher. Nós morando em uma comunidade. Entăo, até por número năo iria dar nada certo. Eu preferi sair para me afastar dessa mulher. Acabei me afastando dos parentes e gostei de viver fora do apoio familiar, ou seja, viver por mim mesmo. Eu era terceiro sargento da paraquedista. Devido esse acontecimento, dei baixa e sai com vinte dois anos e até hoje năo voltei. Só fui lá em 1992 para passear e voltei de novo. Na época eu morava em Santos; eu era pescador. Voltei para Santos e nunca mais fui para o Rio de Janeiro. Bom, primeiro, eu náo saí do Rio de Janeiro direto para rua. Eu era pescador, morava em Santos. Lembro como se fosse hoje. Eu morava na rua Amador Bueno 1262, terceiro andar. Morava na Rua Amador Bueno em frente ao Cemitério. Era pescador. Depois desembarquei, năo quis mais ser pescador e fui ser peixeiro. Aí comprei um triciclo e fui ser peixeiro, graças a Deus. Durante oito anos arrumei mulher, morei com mulher. Santos, na época, era um lugar que tinha muita mulher; era o berço o berço da vida noturna do Brasil. Entáo, separei da mulher. Anda para um lado, anda para o outro e tal. Entăo, conheci muitos Estados e tem uns 10 anos que eu conheci Goiânia e Goiás. E parei por aqui em Goiânia; vim parar por aqui. Eu era pecador, depois trabalhei com reciclagem, catando reciclagem na rua. Sempre deu para me sustentar graças a Deus. Tive muito envolvimento com pessoas boas, pessoas ruins e envolvimento com droga de preferência o álcool. Gostava muito de 'pau podre', a gente fala a maconha. De uns 15 anos para cá só o álcool mesmo, mas usei muita maconha.

[Como é estar em situaçăo de rua?]

O outro me vê como fraco. Como posso explicar? É quando a pessoa te vê, assim, sem um poder. Sem poder falar, expor suas ideias, sua vontade, entende? Sem um poder aquisitivo, por mínimo que seja, entende? Às vezes você acorda todo doido para tomar um café e tem que pedir, por exemplo [choro]. Eu às vezes năo precisava pedir, pois tinha onde chegar. $\mathrm{O}$ dono do comércio já me conhecia. Eu sempre trabalhei com reciclagem. Entăo, você passa a ser conhecido. Por isso, eu tinha facilidade de conseguir almoço e janta para mim. Eu tinha facilidade, entendeu? Eu mesmo nunca gostei de pedir dinheiro. Nunca gostei mesmo. É princípio de casa. A minha măe falava: "Quer dinheiro, vai trabalhar!".

[Entăo, as pessoas que vivem nas ruas trabalham?]

Sim. Muitas pessoas que vivem nas ruas trabalham. Eu acho essa ideia mentirosa, de acreditar que as pessoas que vivem nas ruas năo trabalham. Tem muitas pessoas que está morando na rua e trabalha. Por exemplo, eu catei reciclagem, eu engraxei sapato e engraxo até hoje. Tanto é que tenho meus materiais guardados. Tem outros que vendem bala e eu conheço chefe de família que mora na rua. Dorme na rua com dois, três filhos e está vendendo bala, está trabalhando, está catando reciclagem está trabalhando [Silêncio].

[Você disse como o outro te vê. E você como se sente?]

Eu me sentia fraco. Estou morando na rua! Você năo pode deitar a cabeça e falar 
hoje eu vou dormir e amanhâ vou acordar. A gente vê muita violência. Mesmo nâo participando. Nâo participando, quero dizer, assim, sendo uma vítima dela, entendeu? Mas você vê muita, vê muito [fala inconformado]. Falar que nâo vê violência nesse mundo de Deus é mentiroso, é mentiroso. Hoje acredito que sou o filho do altíssimo feliz da vida, entendeu? Năo é porque eu me encontro dentro de uma casa de recuperaçáo que eu me sinto deixado. Mesmo estando longe da minha família, eles estâo perto de mim, eu nunca me afastei deles. Estăo sempre no meu coraçăo. Entăo, me sinto bem, me sinto bem, nâo me sinto mal, năo. Graças a Deus sou fácil de fazer amigos e colher amizades, procuro ser sempre sincero [choro].

Assim como Joăo José, Oswaldo Silva passou a viver em situaçấo de rua devido a problemas familiares. Ele também relata vício em substâncias químicas. Em sua narrativa, ele demonstra orgulho em dizer que já teve um endereço fixo - apesar do tempo, ainda o sabe de memória. Algo que Oswaldo traz em sua narrativa é o reforço de que a situaçăo de rua nâo é sinônimo de "ociosidade". Semelhante a Joăo José, ele também apresenta uma reivindicaçăo: desmentir a falácia de que pessoas em situaçăo de rua nâo trabalham, ainda que diferentemente do conceito hegemônico de trabalho. Busca, dessa forma, desconstruir uma representaçáo identitária que pesa sobre ele e sobre as pessoas que se encontram na mesma situaçáo.

Segundo Oswaldo Silva, as pessoas nessa circunstância estâo tentando sobreviver, alimentar suas famílias, mesmo com uma renda escassa e inconstante. Por isso, ainda assim, constantemente experienciam a fome. A reinvindicaçăo de Oswaldo Silva corrobora pesquisa realizada pelo Ministério de Desenvolvimento Social e Combate à Fome, quando aponta que "70,9\% das pessoas em situaçâo de rua exercem alguma atividade remunerada [...]. Dessas atividades destacam-se: catador de materiais recicláveis $(27,5 \%)$, flanelinha (14,1\%), construçăo civil $(6,3 \%)$, limpeza $(4,2 \%)$ e carregador/ estivador (3,1\%)" (BRASIL, 2008, p. 10).

Outro fator destacado da narrativa de Oswaldo Silva diz respeito à imposiçấo da colonialidade do poder, do saber e do ser a partir do olhar do outro. Ele diz: O outro me vê como fraco, como posso explicar? É quando a pessoa te vê, assim, sem um poder. Sem poder falar, expor suas ideias, sua vontade, entende? A representaçăo identitária construída pelo discurso outro é um fator de crise em sua identidade pessoal. Como afirma Maldonado-Torres (2007, p. 162), essa imposiçấo leva a sua "invisibilidade ou visibilidade distorcida". Assim, o sentimento de ser fraco é assimilado e reelaborado por Oswaldo Silva, que o assume como sendo seu. Essa invisibilidade ou visăo distorcida de Oswaldo Silva, bem como de Joăo José, pode ter consequências desastrosas, uma vez que "a história tem nos mostrado que a invisibilidade mata [...]. A reflexăo fundamental a ser feita é perceber que, quando pessoas negras [em situaçăo de rua] estâo reivindicando o direito a ter voz, elas estáo reivindicando o direito à própria vida" (RIBEIRO, 2017, p. 26).

Desse modo, as narrativas trazidas aqui se mostram como açóes de reinvindicaçăo e denúncia daqueles/as que estâo em situaçăo de rua, ao mesmo tempo em que oportunizam um encontro com as subjetividades e, consequentemente, a humanidade, desses sujeitos. 


\section{DESAFIOS E DESEJOS QUE PERMANECEM}

Como discutido, a lógica da colonialidade nos faz entender o fenômeno da situaçăo de rua "como algo externo e desumanizado", e a ausência de "reflexăo sobre as condiçôes que levaram essas pessoas até ali, pode causar um efeito de naturalizaçâo que mascara o problema e, assim, restringe políticas públicas eficientes" (RAMALHO; RESENDE, 2018, p. 3). Além disso, pode favorecer a violência e extermínio desse grupo de pessoas (RESENDE, 2016), como relatado na epígrafe que abriu este texto. Por isso, ao trazer as vozes de duas pessoas em situaçáo de rua, por meio de suas narrativas, empreendemos um esforço de(s)colonial, na expectativa de possibilitar que a sociedade que assiste, ou até mesmo pratica, violência e morte desses indivíduos consiga construir um atitude mínima de solidariedade emocional com essas vítimas (MAYA NETO, 2018). Também construímos uma expectativa mais utópica, que se baseia na confiança de que a sociedade pode combater e destruir regimes históricos necropolíticos ${ }^{10}$ e edificar, em seu lugar, paradigmas históricos baseados na justiça, igualdade e dignidade social. Para isso, convidamos o leitor ou a leitora para uma escuta atenta e empática de vozes que a sociedade insiste em silenciar, buscando construir, por meio uma interlocuçâo eticamente solidária, narrativas e histórias outras a respeito das pessoas em situaçáo de rua no Brasil.

Compreendemos que a opçâo pela ótica de(s)colonial năo nos isenta de contradiçôes e tensōes. Ao buscarmos modos de trazer falas/vozes de pessoas em situaçâo de rua, corremos o risco de nossas próprias vozes, assim como as de autores/as com os quais dialogamos, terem se sobressaído ou falado mais alto. Esperamos, contudo, que este trabalho contribua na insurgência de vozes marginalizadas, provocando fissuras na condiçăo de apagamento desse grupo da populaçâao brasileira. Se esse intento năo for alcançado em totalidade, ao menos o desejo de Oswaldo Silva, acreditamos ter realizado:

Quero que meu nome verdadeiro apareça na sua pesquisa. Estou cansado de ser apagado. [...] Eu prefiro usar meu nome. Ele é bonito, né?

Oswaldo Silva

\section{REFERÊNCIAS}

BALLESTRIN, Luciana. América Latina e o giro decolonial. Revista Brasileira de Ciência Política, Brasília. n. 11, p. 89-117, mai./ago. 2013.

BENTO, Berenice. Necrobiopoder: Quem pode habitar o Estado-naçâo? Cadernos Pagu, n. 53,13 set. 2018 .

BRASIL. Ministério do Desenvolvimento Social e Combate à Fome. Sumário Executivo. Pesquisa nacional sobre a populaçâo em situaçāo de rua. Brasília: MDS. Secretaria de Avaliaçấo e Gestăo da Informaçăo, Secretaria Nacional de Assistência Social, abr. 2008. 
BRASIL. Decreto Presidencial n 7.053, de 23 de dezembro de 2009. Institui a Política Nacional para a Populaçâo em Situaçâo de Rua e seu Comitê Intersetorial de Acompanhamento e Monitoramento, e dá outras providências. Diário Oficial da Uniâo, Seçấo 1, 24 dez. 2009a.

BRASIL. Ministério do Desenvolvimento Social e Combate à Fome. Rua: aprendendo a contar: Pesquisa nacional sobre a populaçâo em situaçâo de rua. Brasília: MDS. Secretaria de Avaliaçăo e Gestăo da Informaçăo, Secretaria Nacional de Assistência Social, 2009b.

BRASIL. Ministério da Saúde. Boletim Epidemiológico 14. Populaçăo em situaçăo de rua e violência - uma análise das notificaçôes no Brasil de 2015 a 2017. Secretaria de Vigilância em Saúde. v. 50, n. 14, 2019. Disponível em: http://portalarquivos2.saude.gov. br/images/pdf/2019/junho/13/2019-010-publicacao.pdf. Acesso em: 4 jul. 2019.

BRUM, Eliane. Cem dias sob o domínio dos perversos. El País, Brasil, 12 abr. 2019, Opiniăo, s/p. Disponível em: https://brasil.elpais.com/brasil/2019/04/10/opinion/1554907780_837463.html. Acesso em: 10 jul. 2019.

DENZIN, Norman K.; LINCOLN, Yvonna S. (ed.). The landscape of qualitative research. 4th ed. Thousand Oaks: Sage Publications, 2013.

FANON, Franz. Os Condenados da Terra. Rio de Janeiro, RJ: Editora Civilizaçăo Brasileira, 1968.

FIGUEIREDO, Carlos V. da. S. Estudos subalternos: uma introduçăo. Raídos, Dourados, MS, v. 4, n. 7, p. 83-92, jan/jun. 2010.

IPEA - Instituto de Pesquisa Econômica Aplicada. Atlas de vulnerabilidade social dos municípios brasileiros. Brasília: Ipea, 2015. Disponível em: http://ivs.ipea.gov.br/images/publicacoes/Ivs/publicacao_atlas_ivs.pdf. Acesso em: 28 dez. 2017.

JOVCHELOVITCH, Sandra; BAUER, Martin W. Entrevista narrativa. Pesquisa qualitativa com texto, imagem e som: um manual prático, v. 4, p. 90-113, 2002.

LINO, Tayane Rogeria. O lócus enunciativo do sujeito subalterno: fala e emudecimento. Anuário de Literatura, Florianópolis, v. 20, n. 1, p.74-95, 2015.

MALDONADO-TORRES, Nelson. Sobre la colonialidad del ser: contribuciones al desarrollo de un concepto. In: CASTRO-GÓMEZ, Santiago; GROSFOGUEL, Ramón. (ed.). El giro decolonial: reflexiones para una diversidad epistémica más allá del capitalismo global. Bogotá: Siglo del Hombre Editores, 2007. p. 127-168.

MALDONADO-TORRES, Nelson. On the Coloniality of Human Rights. Revista Crítica de Ciências Sociais, n. 114, p. 117-136, 2017. 
MALDONADO-TORRES, Nelson. The decolonial turn. In: POBLETE, Juan. (Ed.) New Approaches to Latin American Studies: Culture and Power. New York and London: Routledge, 2018. p. 111-127.

MAYA NETO, Olegario da C. Necropolítica da colonialidade no Brasil: segregaçâo e desumanizaçăo no Hospital Colônia de Barbacena e na Cracolândia, em Sâo Paulo. MERIDIONAL Revista Chilena de Estudios Latinoamericanos, n. 11, v. 11, p. 149-177, 2018.

MBEMBE, Achille. Necropolítica: biopoder, soberania, estado de exceçâo, política da morte. Trad: Renata Santini. Revista Arte e Ensaios, v. 16, n. 33, p. 123-151, 2016.

MIGNOLO, Walter. Local histories/global designs: coloniality, subaltern knowledges, and border thinking. Rev. Ed. Princeton: Princeton University Press, 2012.

MIGNOLO, Walter. Colonialidade: o lado mais escuro da modernidade. Rev. bras. Ci. Soc., Sầo Paulo, v. 32, n. 94, p. 1-18, 2017.

MIGNOLO, Walter. Decoloniality and Phenomenology: The Geopolitics of Knowing and Epistemic/Ontological Colonial Differences. Journal of Speculative Philosophy, v. 3, n. 3, p. 360-387, 2018.

PENNYCOOK, Alastair. Language and mobility. Unexpected Places. Bristol: Multilingual Matters, 2012.

QUIJANO, Aníbal. Colonialidad del poder y clasificación social. In: CASTRO-GÓMEZ, Santiago; GROSFOGUEL, Ramón. (ed.). El giro decolonial: reflexiones para una diversidad epistémica más allá del capitalismo global. Bogotá: Siglo del Hombre Editores, 2007. p. 93-126.

RAMALHO, Ingrid; RESENDE, Viviane. O caso Edvan Lima e a corporeidade de pessoas em situaçâo de rua em casos de violência: análise de dados do Jornal Correioweb. Cadernos de Estudos Linguísticos, v. 60, n. 3, p. 808-827, 2018.

RESENDE, Viviane de Melo. Representaçăo de pessoas em situaçăo de rua no jornalismo on-line: quais sâo as vozes convocadas para falar sobre a situaçâo de rua? Revista de Estudos da Linguagem, v. 24, n. 3, p. 955-988, 2016.

REZENDE, Tânia F. Posfácio. In: SILVESTRE, Viviane P. V. Colaboraçâo e crítica na formaçâo de professores/as de línguas: teorizaçōes construídas em uma experiência com o PIBID. Campinas - SP: Pontes Editores, 2017. p. 279-289.

RIBEIRO, Djamila. O que é lugar de fala?. Belo Horizonte: Letramento Editora, 2017. 
SILVESTRE, Viviane P. V. Colaboraçâo e crítica na formaçâo de professores/as de línguas: teorizaçōes construídas em uma experiência com o PIBID. Campinas - SP: Pontes Editores, 2017.

SMITH, Linda T. Decolonizing methodologies: research and indigenous peoples. 2nd ed. New York: Zed Books, 2012.

SPIVAK, Gayatri C. Pode o subalterno falar? Belo Horizonte: Editora UFMG, 2010. 